\title{
Pedagogical Renewal in Portugal Between the 1950s and the 1970s: Actors, Reception of Ideas, Educational Experiences $^{1}$
}

\author{
Joaquim Pintassilgo
}

Universidade de Lisboa

Alda Namora de Andrade

Universidade de Lisboa

\begin{abstract}
This article aims to reflect on the appropriations of pedagogies presented as alternatives to the so-called traditional pedagogy, in Portugal, from the 1950s to the 1970s, whilst under an authoritarian regime. Furthermore, it aims to assess the role played in this movement by a group of educators who were considered progressive. We also propose, within this framework, to think through the complexity of the relations between tradition and innovation, using the concept of "tradition of innovation" as a reference point.
\end{abstract}

Keywords: tradition, innovation, progressive pedagogy, appropriation, mediating intellectuals 


\section{Renouvellement pédagogique au Portugal entre les années 50 et les années 70 : acteurs, réception d'idées, expériences éducatives}

\section{Résumé}

Cet article vise à réfléchir sur les appropriations de pédagogies présentées comme alternatives à la pédagogie dite traditionnelle, au Portugal des années 50 aux années 70 , sous régime autoritaire. II vise également à évaluer le rôle joué par un groupe d'éducateurs considérés comme progressistes dans ce mouvement. Nous proposons également de réfléchir sur la complexité des relations entre tradition et innovation, telles qu'exprimées dans ce contexte, en référence au concept de « tradition d'innovation ".

Mots-clés: tradition, innovation, pédagogie progressive, appropriation, médiateur intellectuel

\section{Renovación pedagógica en Portugal entre los años 50 y los años 70: actores, recepción de ideas, experiencias educativas}

\section{Resumen}

Este artículo tiene como objetivo reflexionar sobre las apropiaciones, en Portugal de los años 50 a los 70 , luego en un contexto autoritario, de pedagogías que se presentaron como alternativas a la llamada pedagogía tradicional y evaluar el papel desempeñado en este movimiento por un grupo de educadores considerados progresistas. También vamos a reflexionar sobre sobre la complejidad de la relación entre tradición e innovación, tal como se expresa en este contexto, teniendo como referencia el concepto de "tradición de innovación."

Palabras clave: tradición, innovación, pedagogía progresiva, apropiación, mediador intelectual

\section{Introduction}

In Postwar Portugal, and in particular after the 1950s, although still in an authoritarian context, there was a conscious effort to promote a pedagogical renewal, developed within the margins of the regime and led by educational agents who were in many cases in the field of political resistance. As key figures of this movement, intellectuals and educators such as Rui Grácio, João dos Santos, Maria Amália Borges Medeiros and Sérgio Niza inspired and helped to develop a set of alternative educational 
experiments. Their main goal was to provide education for citizenship, as well as to put in place new conceptions of teacher training, child protection and special education. These educators were decisive in receiving and disseminating a set of innovative ideas that were already circulating internationally, in trying to introduce these ideas in Portugal in a creative manner, as way to contribute to the future implementation of a democratic society.

The goals of this essay are therefore to reflect on the appropriation, in Portugal, from the 1950 s to the 1970 s, of pedagogies that present themselves as alternatives to the so-called traditional pedagogy and to assess the roles played in this movement by a group of educators considered progressive and framed here through the category of the "mediating intellectual."

This category was extensively explored, in the field of education, by Gomes and Hansen (2016) to account for a set of historical subjects who, while perhaps not directly involved in the creation of cultural goods, emerge as key figures inasmuch as they enable these goods to circulate and reach wider social groups. In the act of reception, these "mediating intellectuals" contribute to the assignment of new meanings to these goods and design strategies for their diffusion by drawing on sociability sites and networks. They are not, therefore, mere knowledge transmitters or popularizers, but rather creators of hybrid products, which elevates their social role. Moreover, as the authors note, an intellectual can be both a "creator" and a "mediator" - which holds true, we believe, in the case the educators under study here.

We shall also call on the notion of a "tradition of innovation", as formulated by Burke (2007), for it allows us to cast a complex, non-dichotomous gaze on the relation between tradition and innovation. For this author, tradition in education should not be perceived as negative by default, just as innovation should not be perceived as positive in and of itself. Both should be understood as plural, dynamic and interconnected. A paradoxical concept such as this one is what enables us to understand how certain innovative movements, namely New Education and the Modern School Movement, can lead to the creation of enduring traditions, still very much present in today's educational contexts, and how, despite their already long history, they can maintain an aura of innovation.

The research whose partial results we present here takes Cultural History as its main source of theoretical inspiration. We draw on some of the concepts used in this disciplinary field, such as representations, practices, circulation and appropriation (Chartier, 2002). Our point of view will bear into account the modalities of circulation of these representations and the way they were appropriated in different contexts. It will prove crucial, therefore, to enter into a dialogue with the latest global and transnational approaches, as many of these models and practices have circulated internationally, being appropriated locally by politicians and educators (Fuchs, \& Roldán Vera, 2019). We will use the entire body of work of these educators as sources, and examine their contents. 
As we see it, the relevance of a research study such as the present one is bound to the desire to question common sense discourses in the field of education and to contribute to an awareness, by today's educators, of the need to incorporate elements of a memory of innovation into their pedagogical wisdom and into their repertoire of educational practices.

\section{From the Educação Nova2 "Moment" to the Escola Activa "Moment"}

The notion of "moment" is important in understanding the trajectory of innovative ideas (Robert \& Séguy, 2020), particularly in the Portuguese case. In the last decades of the 19th century and in the transition to the 20th, that is, in the period that precedes New Education itself, one can already get a glimpse of some of the ideas the latter would come to embody. Nanine Charbonnel calls it the "Compayré moment" (Charbonnel, 1988), Marta Carvalho the "modern pedagogy" (Carvalho, 2001) and Maria del Mar del Pozo Andrés "regenerationism" (Pozo Andrés, 2005), each referring to their own national context (French, Brazilian and Spanish). This is a moment significantly marked by the prevalence of the intuitive method and object lessons, although several other innovative ideas were already emerging.

The first decades of the 20th century, partly coinciding with the First Portuguese Republic (a secular and patriotic regime), are the moment of New Education par excellence, when the main theses that characterize this "Copernican revolution" come forward. Amongst those theses, the following stand out: the affirmation of the scientificity of pedagogy; the placing of the child at the centre of the educational process; an ideal of holistic education, implying the valorization of areas such as manual work, physical education and aesthetic education; the belief in the necessary communion with nature, of which outdoor schools and school Tree Fests ${ }^{4}$ are prime examples; the promotion of a practical and concrete teaching based on the intuitive process and object lessons; the investment in active methods, namely gravitating towards project work and focusing on the learners' interests; and finally, the realization of the project of moral and civic education through schools' self-government (Pintassilgo, 2018).

During this period a wide range of educational experiments were developed within the framework of the ideology of New Education, above all the emblematic Escola Oficina $N^{\circ}$ 1, to which we may add Jardim Escola João de Deus, Instituto de Odivelas, Casa Pia de Lisboa or A Voz do Operário (Candeias, 1994; Figueira, 2004; Pintassilgo \& Alves, 2019). These were not exactly "New schools", if we keep in mind the paradigm of Adolphe Ferrière's 30 points $(1915,2015)$, but rather institutions where the effort to put into practice many of the principles underlying this model was visible. At the same time, a vast group of intellectuals and educators appropriated the movement's theses and promoted their circulation in Portugal through books and leaflets, articles in the 
pedagogical press as well as pedagogical and didactic manuals, to name but a few. The names of Adolfo Lima, Faria de Vasconcelos, António Sérgio, Álvaro Viana de Lemos, João de Barros, João de Deus Ramos, António Aurélio da Costa Ferreira, Irene Lisboa and Frederico Ferreira de Simas, among many others, stand out in this endeavour (Nóvoa, 2003).

The following decades, in which several authoritarian regimes became institutionalized, namely the Portuguese one, under Salazar, one can point to several conservative and, in some cases, Catholic appropriations of New Education. The slogan "active school", propagated by Adolphe Ferrière, was at that time interpreted locally in a rather different sense (Pintassilgo \& Andrade, 2018). The rejection of secularism, self-government, coeducation, the Unified school and internationalism are some of divergences from the previous moment. Even so, we can still find in these cases quite a few commonplaces of New Education, even if their presence is merely rhetorical, as in the cases of a critique of the so-called traditional school and of teaching centered on verbalism and memorization of contents, the belief in a holistic education (even if permeated with Catholicism) or the defence of active teachinglearning methods. The following passage, taken from a teacher's training manual on didactics, by Orbelino Geraldes Ferreira and José Maria Gaspar, is an excellent example of the hybridism that characterizes this pedagogical approach:

We are, as can be inferred from this work, for an active, traditionalist, Christian and constantly progressive school. We are for a Portuguese school. [...] The active school cannot be synonymous with a secular school. [...] We are in favor of a tradition-based school because only thus can we achieve pedagogical work which is nationalist and Christian in practice. (Gaspar \& Ferreira, 1944, pp. 389-391)

In the words of another educator of this period, Moreirinhas Pinheiro (1961), this is pedagogy of the "middle ground", which combines the defence of pedocentrism and activism with the invocation of the values of the Portuguese tradition, particularly Catholicism and nationalism. In the opinion of another author and teacher trainer, Francisco Loureiro, all the methods acquired from New Education were "susceptible to use". Provided, that is, they were subject to "adaptations and corrections imposed by Portugal's particular circumstances", which would purge them from "the whole materialistic and libertarian base, incompatible with the spiritual educational traditions of the Portuguese Nation" (Loureiro, 1950, pp. 126-127). Classics such as Dewey, Decroly, Montessori, Claparède or Ferrière, though often criticized, are not ruled out, but rather subjected to reinterpretations that emptied the political and social dimension of their projects and softened the pedagogical radicalism that was imputed to them, all the while drawing selectively from the innovative didactics they had introduced.

Even if in pedagogical publications it is the "Active School" discourse that predominantly circulates (being the one deemed "politically correct"), the daily school 
life as recalled by former students points instead to the prevalence of authoritarian methods, namely physical punishment, the constant use of practices aimed at retaining knowledge and rituals associated with Catholicism and patriotism (Pereira, 2002).

Many of the innovative educational experiences of the previous period continued throughout the 1930s and 1940s although adapted in some way to this new context and forgoing some of its more radical practices, as in the case of Escola Oficina $\mathrm{N}^{\circ} 1$. Despite the adverse political environment and the need to survive, some were able to maintain more or less discrete links with political resistance to the authoritarian regime. This was clearly the case of Colégio Moderno, founded in 1930s, and also Voz do Operário (Bandeira, 2020) both of which continue to function to this day. These were not propitious times for alternative pedagogies.

\section{The Emergence of a New Moment of Pedagogical Renewal from the 1950s Onwards}

From the mid-1950s onwards, still within the framework of an authoritarian regime, we find a new impetus for the renewal of the Portuguese school. This is a moment with distinctive features that would last until around the mid-1970s, when the democratic revolution of April 25, 1974 radically changed the situation. The educators who played a leading role in this period are part of a generation in which pedagogical progressiveness and opposition to the Salazar dictatorship are deeply intertwined. The struggle for a different school and the struggle for political democratization emerge as two dimensions of the same project. Among them, we can single out the figures of João dos Santos, ${ }^{5}$ Maria Amália Borges Medeiros, ${ }^{6}$ Rui Grácio, ${ }^{7}$ and the younger Sérgio Niza. ${ }^{8}$ On the one hand, these educators sought to root their thinking in the New Education's "tradition of innovation" and, on the other, to engage in a dialogue with new authors and currents whose ideas were widely circulated internationally at the time.

In parallel, from the mid-1950s to the early 1970s, in particular within the private education sector, a number of schools emerged which presented themselves as "alternative" and sought to develop a range of innovative experiments. Among these schools, we can highlight Colégio Eduardo Claparède (1953), Jardim Infantil Pestalozzi (1955), Centro Helen Keller (1955), Externato Fernão Mendes Pinto (1968) and A Torre (1970) (Pintassilgo \& Alves, 2019). Their founders and the teaching staff in this initial phase, together with the previously mentioned educators, constituted an informal network of educators. They sought to bring these experiences to life and to cement the progressive educational field.

The Freinet pedagogy was first disseminated in Portugal between the end of the 1920 s and the early 1930s, mainly on the initiative of Álvaro Viana de Lemos, who attempted to set up an informal network for the dissemination of the so-called "Freinet 
techniques." He and other educators published articles on the school press and corresponded with Freinet himself, but the context - the transition from the Military Dictatorship to the Estado Novo - became more and more at odds with experiments of this kind (Candeias, Nóvoa \& Figueira, 1995; Fernandes, 1998; Figueira, 2004; Nóvoa, 1990). The voice of these educators was silenced and the Freinet pedagogy was thus forgotten for over two decades, having been rediscovered at the end of the 1950s, mainly through the actions of Maria Amália Borges Medeiros, with the collaboration, among others, of Maria Isabel Pereira and Rosalina Gomes de Almeida. Some female Portuguese teachers even attended traineeships in Freinet schools from the early 1960s onwards (Fernandes, 1998; Henrique, 1992).

The Freinet pedagogy eventually became the most important (albeit not the only) source of inspiration for the then growing movement of pedagogical renewal. One of the school experiments in which the "Freinet techniques" had the greatest impact, in the early 1960s, was the aforementioned Helen Keller Centre. According to one author who, in a recent research study, sought to reconstruct the history of this institution, "the use of Freinet techniques was the pedagogical foundation of this school, which deviated from the New State's official system" (Amado, 2019, p. 391). The Centre used the press, produced newspapers, established a school cooperative with an autonomous assembly, started a wall newspaper and encouraged correspondence between students.

The Portuguese Modern School Movement (Movimento da Escola Moderna Portuguesa - MEM), established in the mid-1960s, also incorporated the Freinet pedagogy as a pivotal element of its initial pedagogical model. In 1966, at the Perpignan Congress of the International Federation of Modern School Movements (FIMEM), the Portuguese group, represented by Sérgio Niza and Rosalina Gomes de Almeida, was officially recognised. The movement would develop several initiatives and gradually establish itself in the transition from the 1960s to the 1970s, but only after the Revolution of the 25th of April 1974 was it possible to start the publication of their Bulletin (1974), to formalize its status as an association (1976) and to hold their I Congress (1979), becoming the main organised pedagogical movement in Portugal. Its pedagogical model, however, would be reconfigured over time, departing from its initial inspiration - very marked, as we have seen, by the Freinet pedagogy - and beginning to draw, rather, on socio-cultural constructivism (González, 2002; Pessoa, 1999; Pintassilgo \& Andrade, 2019).

\section{The Appropriation of the New Education Tradition by the Renewal Movement from the 1950 s to the 1970 s}

One of the primary sources of the pedagogical thought of the generation of educators that we have been tracing here is, without a doubt, the very tradition of innovation of 
the New Education movement, even for those who, as was the case of Sérgio Niza, were trying to break with that tradition. Reading through the texts of these four educators we find constant references to the New Education authors or to some of their main theses. One recurrent idea is that the legacy of New Education was yet to be fulfilled. In the opinion of João dos Santos, "Maria Montessori and Decroly lived a century ago, and the authorities continue to ignore their experimental pedagogy" (Santos, 1983, 1991, Vol. II, p. 57).

Pedocentrism is strongly present in the works of João dos Santos and Maria Amália Borges Medeiros, for example. As the first has it, "all education must be based on a love for the child" (Santos, 1982, 1991, Vol. I, p. 41) and "human knowledge results from the possibility, afforded to the child, of learning freely and spontaneously" (Santos, 1982, 1991, Vol. I, p. 163). While the latter claims: "From Rousseau, and through all the great pedagogues of the active school, from Pestallozi to Dewey and Freinet, one of the basic principles, widely accepted, is the respect for the child within the child" (Medeiros, 1972, 1975, p. 121). For Rui Grácio, also, it is the student who is at the centre of the educational process, hence one must speak of "learning" rather than "teaching"; this because "the axis of pedagogical action has shifted from the teacher to the student, who is the starting point, the centre of gravitation of the educational system", and one must take into account his or her "needs" and meet his or her "interests" (Grácio, 1946, 1995, Vol. I, p. 30).

Activism is another of the cornerstones of the New Education ideology that is also invoked. For Maria Amália Borges Medeiros, "implicit in all active pedagogy is a psychology that tells us that one learns best from what one has done for oneself, which is Dewey's 'learning by doing', interpreted in a very broad sense. One learns by doing" (Medeiros, 1972, 1975, p. 58). The idea that "education and teaching must prepare for life" is defended by João Santos, among others (Santos, 1982, 1991, Vol. I, p. 41). The thesis that the concrete practice of small-scale democracy within the school microcosm is central in the formation of future citizens is present in the work of Rui Grácio when he advocates the "tailoring of school life to the principles of selfgovernment and self-support" (Grácio, 1959, 1996, Vol. III, p. 34). Maria Amália Borges Medeiros' contribution to a different understanding of the student's moral and civic education points in the same direction: "all the great names in active pedagogy are concerned with the civic and moral education of the child, from action, from life, from integration into a group" (Medeiros, 1972, 1975, p. 58).

In a number of his texts, Sergio Niza betrays the fact that his thought is rooted in New Education, namely when he claims, in a reference to the Modern School Movement, that "we root our pedagogy in the cultural tradition that comes from Claparède" (Niza, 1987, 2012, p. 96) and when, speaking of co-operative learning, he considers that it was "John Dewey's effort in this field [...], which provided the conceptual apparatus for the most recent research work" (Niza, 1998, 2012, p. 357). These statements seem to presuppose, to an extent, an acknowledgement of this 
lineage. And yet, as we shall see below, Sergio Niza's position is a much more complex and ambivalent one.

As far as the Portuguese New Education Movement is concerned, António Sérgio who is the key reference in the thinking of educators from the 1950s to 1970s, in particular through his work Educação cívica (1915). In this work the principles of school self-government are systematized and the school-council proposed as an autonomous form of organization which, as we have already seen, Sérgio Niza sought to put in place as a young teacher. António Sérgio's influence is also a result of his role as one of the pioneers of cooperativism in Portugal. The concept of cooperation will become central to the alternative pedagogy of that period, partly due to its articulation with the Freinet legacy, recently rediscovered at that time. In a text on António Sérgio and his ideas, Rui Grácio states the following when referring to the "laboratory schools" that he advocates, which were also inspired by the likes of Kerschensteiner, Washburne, Dewey, Maria Montessori or Cousinet, although adapted to the Portuguese context: "The schools in question, as he sees them, were organized according to two or three key pedagogical, or rather, socio-pedagogical, principles. This would make them a kind of typical and purified prefiguration of the democratic municipality (Civic Education) (Grácio, 1959, 1996, Vol. III, p. 34)

Sérgio Niza highlights the role of António Sérgio when reviewing the Portuguese authors and educators who contributed most to the formation of his thought as well as to the construction of the Modern School Movement's ideology. Here he takes the opportunity to underline the ideas of the essayist who inspired him the most: "And in our midst, the legacy of António Sérgio extends the ideas of the cooperative work of learning and democratic training to the idea of a society based on a system of cooperative organization, free from intermediaries and emancipated from state tutelage" (Niza, 1998, 2012, pp. 357-358).

This rooting in the New Education ideology does not mean that this generation of educators subscribes to all the principles of these prestigious. One of the points in which, for example, Rui Grácio disagrees from the discourses of New Education has to do with the dichotomy between traditional education and New School. This duality, typical of the innovative rhetoric of the first decades of the twentieth century, is questioned by Grácio, in trying to put forward a combination between tradition and innovation:

What characterizes modern education as opposed to traditional education? [...] One would have to start by knowing whether we would ground the confrontation on the plane of concepts or facts and what the boundaries are between "modern" and "traditional", etc., etc. To consider whether they are always in opposition. I would also note the following: in the past there were many experiences, as well as reflections - by philosophers, pedagogues, moralists - around ideals and formative 
processes of man that have not become obsolete, but rather have taken on a renewed interest in today's world. (Grácio, 1968, 1996, Vol. I, p. 245)

João dos Santos, whilst recognizing the importance the progressive tradition had in his own formation, is aware of the outdated nature of this legacy and how it had become stale, which pushed him to consider how to overcome it:

My dream is the result of having, in the meantime, taken notes from Froebel, Pestalozzi, Montessori, Decroly, Dewey, Claparède and others. But the works of these great pedagogues seem to have been cramped by a mechanized and soulless teaching. Some of these have perhaps been surpassed, but Freinet for example, one of the greatest of our time, is unfortunately rarely followed. (Santos, 1982, 1991, Vol. I, p. 36)

In his opinion, as we can see, it is the contribution of Freinet, another of the masters associated with this heritage (but who had distanced himself from it), that would enable its revival in the Portugal of that time. We shall return to this subject later on. It is Sérgio Niza, in particular, at a later moment, who seeks to cut the umbilical ties with New Education. The author's dissociation from the pedocentrism which, in his view, characterized this pedagogical moment, seems to us quite clear. An example of this can be seen in the following statement: "Our struggle has always been with children and never for children" (Niza, 1978, 2012, p. 57). The greater emphasis laid on social constructivism, evident since the 1980s, also led to a certain distancing from a proposal that was seen as prone to individualism: "Since then, a clearer idea of the social construction of learning has led us to a better understanding of certain ambiguities and contradictions, fueled by the individualistic choices of Claparède's functionalism that Freinet was so drawn to" (Niza, 2001, 2012, p. 411). This last statement should not surprise us, bearing in mind that it is also here that some separation from the French master begins to emerge. In another text, as he tries to define three central categories in the context of this debate, Sérgio Niza underlines what, in his view, most differentiates these various currents: unlike the New School, centred on the student, and the traditional school, centred on the teacher, the Modern School, which he champions, focuses rather on the cooperative relationship between all school agents. The Modern School thus emerges as the formula that allowed for the New School to be overcome:

The Modern School is the school proposal that stands up against the 'New school'. At the very moment when the 'New School', as an active pedagogy, was beginning to come into play at European level, it already contained the seeds of its own decadence, since it was already highly bureaucratized and academized. The Modern School Movement, emerging from the 'New School', rose up against the 'New School' to denounce this sclerosis. And for this very reason it manages, as 
the grassroots movement that it is, to sustain itself and renew itself permanently [...]. This entirely new step in the field of pedagogy leads teachers and educators to: fully commit to the practice and theorization of their practice, rather than waiting for 'enlightened' pedagogues to lead the way. (Niza, 1979, 2012, p. 60)

The previous passage is particularly interesting and telling, in more ways than one. The reasons for cutting ties with the New School are further explored here, and it is worth underlining, in particular, the criticism of the institutionalization of this movement and its elitist character, which would have dictated its "decadence". In this new moment of the Modern School, the protagonists would no longer be the "enlightened pedagogues" (to use Niza's own phrase) but, instead, those working on the ground, thus combining theory with practice at the hands of the teachers and educators themselves. It is, therefore, a "grassroots movement" and it is this character that, according to Sergio Niza, favors its permanent renewal. Equally significant is the recognition that, although rising against it, the Modern School emerged from the New school.

\section{Readings and Representations of the Freinet Pedagogy in Portugal from the 1950s to the 1970s}

Freinet pedagogy was, as we have seen, reintroduced in Portugal in the transition from the 1950s to the 1960s, having been appropriated by many of the educators who were looking for alternatives to so-called traditional pedagogy and eventually became the main source of inspiration for many of the different experiments developed in that period. João dos Santos tries to outline the trajectory of this appropriation process when he writes: "It was Viana de Lemos who introduced Célestin Freinet's ideas and techniques to Portugal. We are indebted to Maria Amália Borges de Medeiros for her rediscovery of Freinet's great pedagogical adventure and the methods of the Modern School" (Santos, 1982, p. 21). In one of her texts, she gives us her own account of how this rediscovery took place, almost as a kind of illumination:

One day, whilst working in the amblyopic class of the Portuguese League for the Prevention of Blindness, I discovered Célestin Freinet. And Eureka! [...] The child likes to work and will work hard when the work allows them to solve a problem of their own. Self-expression should be encouraged not only in the artistic field, but also in the intellectual field. To express oneself is to communicate and to communicate one needs interlocutors. The centre of interest is the life of the child who enters the school, it is not an arbitrary construction by the teacher. The school cooperative is governed by the students, and their sense of responsibility, thus stimulated, dignifies and motivates the child. This is a set of ideas that began to have meaning for me when I came into contact with Célestin Freinet's way of 
thinking and his pedagogical techniques. I gained a better understanding of the scope of the word education. (Medeiros, 1972, 1975, pp. 16-17)

We apologize for the lengthy quotation, but it is particularly significant as an account of the intellectual path followed by this generation, one which led them to Freinet. Let us highlight here, in particular, their great appreciation for communication and cooperation, which would become central elements in the constructivist pedagogies that begin to develop from that moment on, as well as the references to the role of child's creative expression, the value of work and to the need to bring the life and problems of children into the school.

Returning to João dos Santos we can see, in addition to the aspects already mentioned (and, in particular, the ideal of cooperation), others that are singled out by this author as embodying the heritage of Freinet, at least the elements the Portuguese educators of his generation assimilated, tied to the ideas of school-workshop and school-work, in addition to the necessary bonds between school and society: "There is Freinet and his disciples who defend the workshop-school, permeable to social life, where every day single day children reinvent the school. They create their texts, make their books, decorate the classrooms and organize themselves cooperatively" (Santos, 1982, 1991, Vol. I, p. 68).

Having emerged out of this same context, it is not surprising that Freinet pedagogy is also the main source of inspiration for the pedagogical ideology of the Modern School Movement when it came into being. Sérgio Niza recognizes this in several of his texts, as in the example that follows, in which he refers to the early days of the Movement:

In Portugal from 1965 onwards, the Freinet Techniques, as his pedagogical proposal was then called, were decisive in sustaining and developing the project of the Working Group for Pedagogical Promotion, created in February of 65, within the scope of the second teachers' professional development course, run by Rui Grácio, in the National Union of Teachers. (Niza, 2001, 2012, p. 410)

According to this author, the most striking aspects of the appropriation of Freinet's ideas were: the contribution of the "cooperative organization of labor" which aimed to create "a democratic education " of children and young people (Niza, 1998, 2012, p. 357); "the practice of free expression at school" as a corollary of living by the principle of freedom (Niza, 1987, 2012, p. 357); the centrality of the printer as "the privileged operator of the communication circuit" (Niza, 1989, 2012, p. 108); and "the pioneering idea of civically engaging teachers in the shared construction of their social and educational practices" (Niza, 2007, 2012, p. 558), i.e. the anticipatory concern with peer teacher training, in close connection with their practice. Although nowadays the Movement no longer identifies itself through this privileged link to Freinet, Sérgio Niza 
recognizes that there are still visible "traces" of this "cultural heritage", particularly in the "instruments for planning and structuring work" (Niza, 2001, 2012, p. 412). It should be noted that these "traces" are still strongly present in the educational practices of many of today's "unconventional" school experiences.

\section{Other Contributions: Non-directive Pedagogies, Institutional Pedagogy and Non-schooling}

Other proposals are also to be found in the educational field during this period, namely institutional pedagogy (rooted in the Freinet movement), non-directive pedagogies, the de-schooling theories and the educational use of strategies inspired by psychoanalysis. Some of these experiences end up combining various sources of inspiration, setting up educational projects marked by hybridity. The Modern School Movement itself, despite the predominance of Freinet pedagogy in its initial phase, was open to other contributions, as Sérgio Niza acknowledges here: "During the first years, Freinet Techniques, Institutional Pedagogy and Non-Directive Procedures in education marked the pedagogical practice of these professionals" (Niza, 1998, 2012, p. 353).

It is very telling, given the level of knowledge of institutional pedagogy that existed in Portugal at that time, that it was Rui Grácio himself who prefaced the Portuguese edition of Michel Lobrot's La Pédagogie institutionelle (A Pedagogia Institucional, 1973). In his view, institutional pedagogy sparked a lively interest among Portuguese educators who sought to contribute in some way to introducing innovations into the educational system. In his own words, the main contribution of institutional pedagogy could be summarized as follows:

Institutional pedagogy tries to trigger, from the teacher-student group and within the perimeter of the class, a pragmatic process of transformation of the insides of, and inside, the school institution itself [...].In the end, it is a question of instituting other institutions, in other words, of making the institution not just a given, but an act (Lobrot), of creating new educational models and original forms of communication and work, turning institutional pedagogy into an instituting pedagogy (R. Loriau). How? By pedagogical self-management within the class, which is the technical instrument of institutional pedagogy. (Grácio, 1973, 1995, Vol. I, pp. 319-320)

Rui Grácio does not fail to express his sympathy for this conception of an "instituting pedagogy" and for the proposal of "pedagogical self-management of the class" which he interprets in a moderate sense, whilst also manifesting a clear knowledge of the currents which converge in institutional pedagogy, as well as of its division into two major trends: 
The reader will have noticed [...] that in this tendency of institutional pedagogy [led by Lobrot] there is a confluence of assumptions and techniques from non-directive pedagogy, from the diagnosis group and from psychosocial intervention in organizations. The other trend in institutional pedagogy in France is tributary to psychoanalysis and Freinet techniques, and is to be found in the experiences of Aida Vasquez, Fernand Oury and others, within primary education. (Grácio,1973, 1995, Vol. I, p. 321)

Rui Grácio thus proves to be familiar with the complexity of the pedagogical world of that time, offering an account of some of his readings, namely those which supported his own interpretation of these various contributions. In fact, the Portuguese educators of the 1950s through to the 1970s knew the works of Freinet, Lobrot, Fernand Oury and also Aida Vasquez, Carl Rogers and Ivan Illich, all of whom were often quoted. They would have predominantly read the French editions of these authors' works, which were available in some libraries in Portugal, but other works were translated into Portuguese between the late 1960s and the early 1970s, i.e., in the last years of the Estado Novo. ${ }^{9}$ In the aftermath of the revolution, these editions and translations multiplied, a question to which we will turn our attention in a later work.

Maria Amália Borges Medeiros was one of the Portuguese educators of this period who demonstrated her knowledge of Carl Rogers' work, and acknowledged her identification with some of the thesis of the American author - namely in terms of his idea of accepting the other, the emphasis on the teacher's authenticity and the selfawareness they must bring to their role as teachers. At the same time, she acknowledged the open way in which she interpreted these ideas, in conjunction with other contributions: "The concept of acceptance of the other, which I also found in the work of Carl Rogers, is of particular interest to me." (Medeiros, 1970, p. 30). Adding, further down: "And here we come to another one of my dilemmas, which is related to the problem of authenticity. [...] Carl Rogers helped me to get a clear perspective on this issue" (Medeiros, 1970, p. 32)

Finally, in a text by João dos Santos we find a reference to Ivan Illich's thoughts on this matter, where he states that "the idea of education as impregnation of the person by society, of which [Ivan] Illich spoke [...] seems to me very acceptable and productive" (Santos, 1983, 1991, Vol. II, p. 172).

\section{A New Role for the Teacher}

In the thinking of the educators of this generation it is evident that, among other things, the traditional role of the teacher is questioned and that an alternative role for them is being sought. Addressing this new conception of the teacher underlying the theorization of institutional pedagogy, and expressing his agreement with this new 
stance - which, in his view, alters the teacher's role and attitude, Rui Grácio summarizes the issue in the following terms: "What happens to the teacher in this system? He is not absent or excluded from it but instead intervenes in accordance with the modalities decided by the students. He is at their disposal and at their service, intervening only when called upon." (Grácio,1973, 1995, Vol. I, p. 340).

Rui Grácio, in line with this conception, was himself an example of this new role in some of the actions that he promoted, such as the already mentioned "Professional Development Courses" organized within the scope of the National Teachers Union, with three editions between 1963 and 1966. He assumes that he led them in a "nondirective" manner, inspired by "group dynamics", experiments in which he had participated during his stay in France. The course was a great success, with the participant teachers writing letters of appreciation for the Union's newspaper. In one of the testimonies, the attitude of the course director, Rui Grácio, is described as follows: "surprising, quiet, subtle, solicitous, patient, enlightened" (Pintassilgo, 2007, p. 28).

This is a wonderful synthesis of what the role of the "non-directive" teacher, that Rui Grácio sought to embody, should be - to bring his constant presence and influence to bear on the construction of the student's self. In another work, as he further described this role, inspired by his master António Sérgio, he states: "Yes, 'the true educator is the method embodied in a man' [...]. And the values embodied in him and explicitly or implicitly proposed in the educational relationship. Proposed, not imposed, for to educate is to provoke, to promote, to emancipate" (Grácio, 1966, 1995, Vol. I, p. 164). The notion of the teacher as a transforming intellectual, theorized later in the field of critical pedagogy, is already clearly present in this eloquent excerpt by Rui Grácio. In any case, the non-directive teacher's attitude cannot be interpreted in a reductive way, in the opinion of Maria Amália Borges Medeiros:

It is not indispensable that students always poke around for answers to the questions they formulate, as certain currents of the active school recommend. The teacher can and must intervene if their intervention is requested, meets a need of the individual or the group and is meaningful for those who listen to them. (Medeiros, 1972, 1975, p. 134)

Medeiros thus clearly distances herself from more radical interpretations of the role of the teacher in non-directive pedagogies. She is adamant in her claim that the teacher can and must intervene as long as there is a need for such intervention on the part of the student. She is aware that the construction of the autonomy of the students is a gradual process, in which only step-by-step can they free themselves from their dependence on the teacher. As she states: "We believe that the art of the educator lies precisely in knowing how to progressively loosen the bonds of dependence that bind them to the learner" (Medeiros, 1972, 1975, p. 128). It is up to the teacher to create an educational environment that promotes the development of projects that are 
articulated with the life and potential interests of the students. One that favors their progressive autonomy: "My task as a teacher, I came to understand, was to create an atmosphere in which projects in the near or distant future could arise and grow within the school and be integrated into each person's individual life " (Medeiros, 1970, pp. 20-21).

The educational value of the teachers themselves, of the values they embody, and the need for them to forge a dense relationship with their students, is also strongly present in the thinking of João dos Santos. According to him, "emotion is at the base of all learning" (Santos In Branco, 2000, p. 98) and education is "strongly permeated by the educator's affections" (Santos In Branco, 2000, p. 108). The author appropriates, in his own way, the traditional notion of the master's exemplarity: "For my part, I have become used to saying that education consists of the person presenting themselves as a model" (Santos, 1982, 1991, Vol. I, p. 24). In any case, this is an open and flexible model that is not imposed on the student, but rather offered as a possibility, a potential.

In the article "The educator's part", published in a Modern School Movement Bulletin in January 1977, we find a suggestive synthesis of the role of the teacher from the Movement's point of view. Among other things, he or she must "be available and adopt a collaborative attitude", "represent the role of model", "respect the personality of each child", "be attentive and sensitive to the role played by affectivity", "develop the social sense of each individual" and "provide them with the necessary working tools " (Bulletin of the Modern School Movement, January 2, 1977, p. 5). It is an image, of course, far removed from the stereotype of the Teacher we find in "traditional teaching", although the traces of continuity with the Teacher as imagined in the context of New Education are obvious.

One specific element which is vitally important to the pedagogical model of the Modern School Movement is the way in which teacher training is perceived. Namely, it is taken as a starting point for the concept of "pedagogical isomorphism", a term which does not yet appear in the initial phase of the Boletim, ${ }^{10}$ even though the idea is already there. The Movement is, by definition and from the start, a space aimed at the teachers' "cooperated (self) training", an expression more recently used to define its purpose and which has always been present in the Bulletin. Much of the news or reports from various parts of the country refer precisely to situations in which teachers (from Modern School Movement and beyond), come together to share experiences resulting from the pedagogical practices developed with their students, an exchange of experiences that has an eminently formative purpose. One of the most defining traits of the Movement from the beginning is this desire to break away from more standardized or traditional forms of teacher education. In this context, teachers appear simultaneously as recipients and agents of this same training, which is developed among peers in a cooperative way to form a learning community using the same 
strategies that should be used by these teachers when working with their students. (Pintassilgo \& Andrade, 2019).

\section{Final Considerations}

The projects and experiences of pedagogical renewal developed in Portugal between the 1950s and the 1970s were closely linked to the political resistance to the authoritarian regime in the last phase of its existence. Pedagogical innovation and education for citizenship, developed through a set of small-scale yet broad-reaching initiatives emerged as part of the struggle for the political democratization of the country. These projects and experiences were grounded on a network of educators, amongst whom João dos Santos, Maria Amália Borges Medeiros, Rui Grácio and Sérgio Niza, singled out here as "mediating intellectuals", but which included many other educators, namely those linked to the creation of alternative schools such as Lucinda Atalaia, in the case of Pestalozzi, and Ana Maria Vieira da Almeida, in the case of A Torre. The Freinet pedagogy, then rediscovered, became the main source of inspiration for these educators and these experiments, although in most cases not exclusively, but rather combined with other proposals such as institutional pedagogy, non-directive pedagogies or even the deschooling theory.

Although rooted in the ideas of New Education, which had its heyday in the first decades of the twentieth century, the conservative and Catholic "active school" followed it as a permutation that perverted the movement's original spirit. The educators linked to the moment of renewal that erupted in the 1950s creatively appropriated this tradition by enriching it with the contribution of pedagogical ideas that were then widely known internationally. Despite the great visibility of the so-called Freinet techniques, this moment is clearly marked by the hybrid nature of its principles, visible both in the works of the authors analyzed here and in the educational projects of the various schools created at the time. It was also in the 1960s that the pedagogical movement with the greatest expression in the Portuguese educational reality, in over half a century, was founded: the Modern School Movement, whose main ideologist was Sérgio Niza. Taking Freinet pedagogy as its starting point, the Modern School Movement took on other contributions during the transition from the 1980s to the 1990 s and began to reclaim the heritage of sociocultural constructivism, especially Vygostsky's theorization. These various branches of a pluralist progressive tradition framed here as true "tradition of innovation" - and many of their postulates, beliefs or commonplaces, still permeate recent efforts of pedagogical innovation in Portugal. It is essential for us to have a critical awareness of this history in our battles for a school of another kind, a utopia that pushes us to identify with the generation of New Education but also with the generation of educators whose trajectory we have tried to follow in this article. 


\section{Notes}

1. This article received national funding from the FCT - Fundação para a Ciência e a Tecnologia, IP, within the scope of the UIDEF - Unidade de Investigação e Desenvolvimento em Educação e Formação - UIDB/04107/2020.

2. New Education

3. Active school

4. The French revolution brought about a flourishing of civic and educational celebrations. The 3rd French Republic incorporated this cult into the institutionalized system of civic festivities. These festivities became celebrated in Portugal during the last years of the monarchy. However, it was only after the establishment of the republic that they became popular (1911). During these festivities, children planted trees as a symbol of regeneration, freedom, solidarity and life - central republican principles. 5. João dos Santos (1913-1987) began his professional trajectory as a physical education teacher and then graduated as a doctor, specializing in child psychiatry. He militated in the political opposition to the authoritarian regime. He worked in Paris with Henri Wallon between 1946 and 1950. Upon his return to Portugal, he became one of the main driving forces behind some of the alternative school experiments developed since the 1950s, such as the Colégio Claparède and the Centro Helen Keller. He developed his own unique approach, which he called "therapeutic pedagogy". 6. Maria Amália Borges Medeiros (1919-1971) graduated in Historical-Philosophical Sciences and was a teacher in both private and state education, from where she was banned as a result of her collaboration with the opposition to the Estado Novo. She set up an experimental school where she experimented with the "Freinet techniques" and ran the Centro Helen Keller for a period. She left for Canada in 1963 to escape political persecution, and there she became a university professor and the editor of educational science journals.

7. Rui Grácio (1921-1991) earned a degree in Historical-Philosophical Sciences and was a teacher at the Lycée Français Charles Lepierre in Lisbon (1947-1972). He militated in the political opposition to the authoritarian regime and was one of the founders of the Socialist Party (Partido Socialista,1973). From 1963 on, he was active in the Pedagogical Research Centre (Centro de Investigação pedagógica) of the Calouste Gulbenkian Foundation. After the 1974 Revolution he was a member of the government (as Secretary of State) and was at the forefront of some of the main reforms introduced during that troubled period.

8. Sérgio Niza (b. 1940) began his professional career in the city of Évora, where he trained as a primary school teacher. He was banned from state education because of his activities in opposition to the regime. He worked at the Calouste Gulbenkian Foundation and the Centro Helen Keller, and was in Paris on a scholarship for a period. He was one of the founders of the Portuguese Modern School Movement (MEM) and, 
through both his writings and actions, became its main theoretical reference and patron.

9. This refers to the authoritarian, autocratic and corporatist state regime that existed in Portugal for 41 uninterrupted years, from the approval of the 1933 Constitution to its overthrow by the revolution.

10. The publication Escola Moderna, owned by the Movimento da Escola Moderna (MEM) appeared in June 1974, in the form of an Internal Bulletin.

\section{References}

Amado, M. R. (2019). Centro Infantil Helen Keller: Educar na diversidade. In J. Pintassilgo, \& L. A. M. Alves (Coord.). Roteiros da inovação pedagógica: Escolas e experiências de referência em Portugal no século XX (pp. 381-413). Lisboa: Instituto de Educação da Universidade de Lisboa.

Bandeira, F. (2020). A Sociedade de Instrução e Beneficência A Voz do Operário: Outra forma de fazer política: A propósito da reforma dos serviços escolares (1924-1935). Cadernos de História da Educação, 19 (1), 187-213. DOI: https://doi.org/10.14393/ che-v19n1-2020-12

Boletim do Movimento da Escola Moderna, 2, janeiro de 1977.

Burke, P. (2007). Cultura, tradição, educação. In D. Gatti Jr. \& J. Pintassilgo (Org.).

Percursos e desafios da pesquisa e do ensino de História da Educação (pp. 15-20). Uberlândia: Edufu.

Candeias, A. (1994). Educar de outra forma: A Escola Oficina No 1 de Lisboa (19051930). Lisboa: Instituto de Inovação Educacional.

Candeias, A., Nóvoa, A., \& Figueira, M. H. (1995). Sobre a Educação Nova: Cartas de Adolfo Lima a Álvaro Viana de Lemos (1923-1941). Lisboa: Educa.

Carvalho, M. (2001). A Caixa de Utensílios e a Biblioteca: pedagogias e práticas de leitura. In D. Vidal, \& M. L. Hilsdorf. Tópicas em História da Educação (pp. 137-167). São Paulo: Edusp - Editora da Universidade de São Paulo.

Charbonnel, N. (1988). Pour une critique de la raison educative. Bern: Peter Lang.

Fernandes, R. (1998). Movimentos de inovação pedagógica no Portugal contemporâneo: Maria Amália Borges e a integração educativa em meados do século. Escola Moderna: Revista do Movimento da Escola Moderna, $5^{a}$ série (3), 2341.

Ferrière, A. (1915, 2015). Prefácio. In A. Faria de Vasconcelos. Uma Escola Nova na Bélgica (pp. 7-20). Aveiro: UA Editora.

Figueira, M. H. (2004). Um roteiro da Educação Nova em Portugal; Escolas Novas e práticas pedagógicas inovadoras. Lisboa: Livros Horizonte. 
Fuchs, E., \& Roldán Vera, E. (Eds.) (2019). The transnational in the History of Education: Concepts and perspectives. London: Palgrave Macmillan.

Gaspar, J. M., \& Ferreira, O. G. (1944). Notas de Didática Especial. Porto: Tip. Domingos de Oliveira.

Gomes, A. C., \& Hansen, P. S. (2016). Apresentação: Intelectuais, mediação cultural e projetos políticos: Uma introdução para a delimitação do objeto de estudo. In A. C. Gomes \& P. S. Hansen (Org.). Intelectuais mediadores: Práticas culturais e ação política (pp. 7-37). Rio de Janeiro: Editora Civilização Brasileira.

González, P. F. (2002). O Movimento da Escola Moderna: Um percurso cooperativo na construção da profissão docente e no desenvolvimento da pedagogia escolar. Porto: Porto Editora.

Grácio, R. (1995-1996). Obra completa (3 Volumes). Lisboa: Fundação Calouste Gulbenkian.

Henrique, M. (1992). Cronologia histórica do Movimento da Escola Moderna Portuguesa. In Vilhena, G, Soares, J., \& Henrique, M. (Orgs.). Nos 25 anos do Movimento da Escola Moderna Portuguesa (pp. 11-18). Lisboa: Movimento da Escola Moderna.

Lobrot, M. (1973). A pedagogia institucional. Lisboa: Iniciativas Editoriais.

Loureiro, F. S. (1950). Lições de Pedagogia e Didática Geral. Coimbra: Livraria Gonçalves.

Medeiros, M. A. B. (1975). As três faces da pedagogia (2a edição). Lisboa: Livros Horizonte ( $1^{\text {a }}$ edição de 1972).

Medeiros, M. A. B. (1970). O papel e a formação de professores. Lisboa: Fundação Calouste Gulbenkian - Centro de Investigação Pedagógica.

Niza, S. (2012). Escritos sobre Educação. Lisboa: Tinta-da-China.

Nóvoa, A. (2003). Dicionário de Educadores Portugueses. Porto: Edições ASA.

Nóvoa, A. (1990). Álvaro Viana de Lemos: Um pedagogo da 'Educação Nova'. Arunce: Revista de Educação Cultural, 3-4, 52-107.

Pereira, S. M. (2002). Memórias da Escola Primária. Lisboa: Livros Horizonte.

Pessoa, A. M. (1999). Movimento da Escola Moderna Portuguesa: 1966-1996 (Dissertação de Mestrado, Universidade de Lisboa).

Pinheiro, J. E. M. (1961). Introdução ao estudo da Didática Especial, para uso dos alunos-mestres das Escolas do Magistério Primário (2. ${ }^{a}$ edição, revista e aumentada). Lisboa: s.n.

Pintassilgo, J. (2018). A Educação Nova em Portugal: Construção de uma 'tradição de inovação'. Historia Caribe, 13 (33), 49-82. DOI: http://dx.doi.org/10.15648/hc.33. 2018.4

Pintassilgo, J. (2007). Associativismo docente e construção da identidade profissional no contexto do Estado Novo: O exemplo do Sindicato Nacional dos Professores entre o final dos anos 50 e o início dos anos 70. Pensar a Educação, 1, 9-32. 
Pintassilgo, J., \& Alves, L. A. M. (Coord.) (2019). Roteiros da inovação pedagógica: Escolas e experiências de referência em Portugal no século XX. Lisboa: Instituto de Educação da Universidade de Lisboa.

Pintassilgo, J., \& Andrade, A. N. (2019). Sérgio Niza e a 'autoformação cooperada': Reflexões em torno do modelo pedagógico do MEM. Revista Lusófona de Educação, 43, 163-179. DOI: 10.24140/issn.1645-7250.rle43.11

Pintassilgo, J. \& Andrade, A. N. (2018). Domingos Evangelista, tradutor de Ferrière: Reflexões a propósito de uma tradução conservadora de «L'École Active». Educação Unisinos, 22 (3), jul / set., 255-263. DOI: https://doi.org/10.4013/edu. 2018.223.03

Pozo Andrés, M. del M. (2005). La renovación pedagógica en España (1900-1939): Etapas, características y movimientos. In E. C. Martins (Coord.). V Encontro Ibérico de História da Educação: Atas: Renovação Pedagógica (pp. 115-159). Coimbra / Castelo Branco: Alma Azul.

Robert, A. D., \& Seguy, J. Y. (2020). The French Classes Nouvelles (1945-1952): Why is it so difficult to Change Traditional Pedagogy? Espacio, Tiempo y Educación, 7 (1), 27-45. DOI: http://dx.doi.org/10.14516/ete.281

Santos, J. (1991). Ensaios sobre educação (2 volumes). Lisboa: Livros Horizonte (1 ${ }^{a}$ edição de 1982-1983).

Santos, J. (1982). A caminho de uma utopia: Um Instituto da Criança. Lisboa: Livros Horizonte.

Sérgio, A. (1915). Educação cívica. Porto: Renascença Portuguesa. 